Research.

\title{
The impact of earning management on market earnings value: the causal study on the level of accruals
}

\author{
Muljanto Siladjaja \\ Department of Accounting, Perbanas Institute, Jakarta, Indonesia \\ muljantosiladjaja@gmail.com \\ Yuli Anwar \\ Department of Accounting, Economic College of Binaniaga, Bogor, Indonesia \\ juli_anwar@yahoo.com
}

Received: August 12, 2019; Accepted: November 7, 2019; Published: December 31, 2019.

To cite this article: Siladjaja, M., \& Anwar, Y. (2019). The Impact of Earning Management on Market Earnings Value: The Causal Study on The Level of Accruals. The Accounting Journal of Binaniaga. 4 (2): 09-20. doi: 10.33062/ajb.v4i2.338

Abstract. The purpose of this research is to test investors capability to detect earning management after the period of publication, when the information from financial report plays critical role in investment's decision. Given the feedback of investor's reaction, this research provides an empirical model, that point out the earnings management as a message or signal of firm performance, particularly of negative perception on accruals's opportunisties. This research uses path model analysis and multivariate regression, where the data have been collected from 2.560 observations. The unit of analysis of this research was all the listed companies in the period 20012017. The method of sampling was purposive sampling, which based on annual financial report. The findings of this research showed that all public firms have systematic method for earnings management, by distinguishing the positive and negative accruals, the discretionary accruals have the negative influence on the market value significantly, when we used the earning market ratio. When financial report had high accruals quality, it had positive perception from investors, while estimating the future prospect with high accuracy by obtaining usefulness of financial report. The indicator of earnings management, and working capital had been sensitive for investors, because of accruals in reporting firm's performance.

Keywords: Discretionary Accruals, Working Capital, Dividend Pay Out, Quality of Accruals, Cost of Capital.

\section{Introduction}

Research about correlation between working capital and profitability was conducted by Lazardis and Tryfondis (2006). They studied about working capital and profitability of companies at Greece's stock exchange by using cash conversion cycle as independent variable and gross operating profit as dependent variable. De Loof (2003) found significant and strong correlation between working capital management and corporate's earning capabilites. The figure below explains the role of working capital on market earning value. 


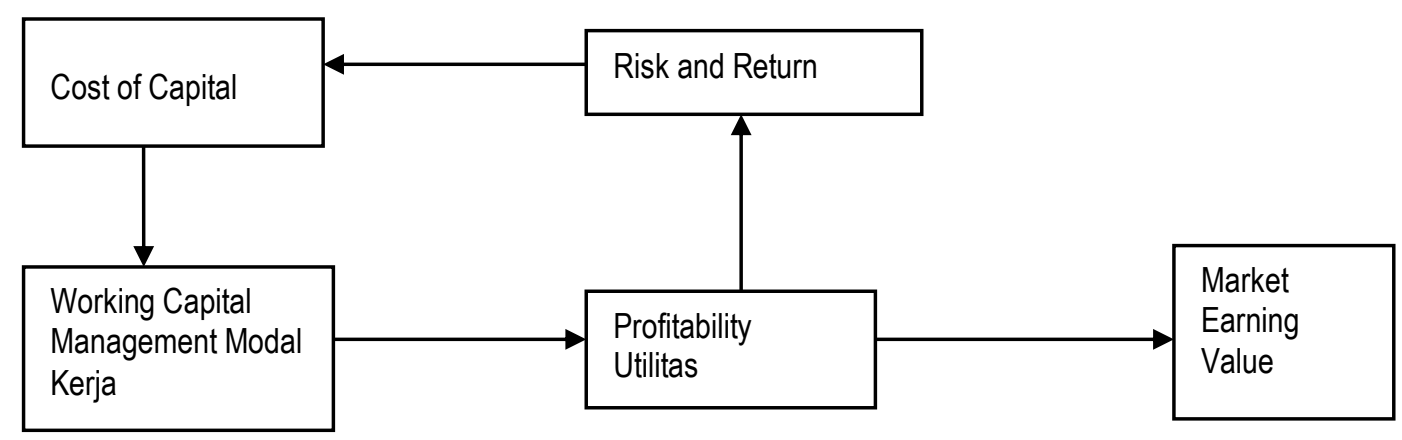

Figure.

Role of Working Capital on Market Earning Value.

Source: Myers (1984); Gombola and Ketz (1983), Soenen (1993) and Lazaridis (2006),

The research using working model management indicator on the accruals' effect conducted by Barth et al (2001) showed there was negative correlation between accruals and working capital management, including into cash and supplies as well as account recievable. Penman and Zhang (2002) used the modelling of working capital management component as future prediction. The result showed that the working capital component and advertising cost as well as product development cost are not predictors because of the accruals's item. Chan et al (2006) stated that there was an effect of accruals on working capital (account recieveable, inventory and negative impact payable accounts).

By comparing the capability of company's working capital in Indonesia, Fransisca (2014) found that management will conduct earning mangement agressively in "not good" condition of company's working capital capability. This study also measured the effect of company's leverage level with company's risk, when the risk increase, the earning management will be applied massively.

Earnings management has attracted academists' attention by the end of 1960 s. Teoh, et al (1998a, 1998b) conducted research on earning management fluctuations in IPO event, the accruals usage occured agressively in the process of open shares bidding. Regarding the case of earnings management in Indonesia, Sylvia (2005) assumed that management has an opportunist characteristic in running company for its personal interests due to the influence of the ownership majority and company's size. Leuz et al. (2003) showed that Indonesia is classified as a country that have weak protection for investors, in which the earnings management occurred. This statement is supported by Myring (2006) that categorized Indonesia as "the emerging markets". Shanty, et. al. (2012) showed that the IFRS adoption has no significant effect to the earnings management. The result analysis showed that statistically there is no significant difference between earning management level, before and after adopting IFRS. This finding does not meet the research expectations that there is a declining in earning management after adopting IFRS.

\section{Problem Identification}

Dechow and Dichev (2002) introduced the concept of accruals quality to measure the company risk. The Management's capability to conduct earning management certainly has "mis-leading" financial report indicators. This research formulated as follows:

1. How does dividend payout impact on market earnings value?

2. How does earning management influence market earnings value, including accrual's impact on dividend policy and working capital management?

3. How does risk impact on market earnings value by using cost of equity and debt ?

4. How does working capital policy impact on market earnings value? 


\section{Benefits of Financial Statements' Information}

The purpose of financial statement analysis is to assess the value of a company. Many accounting empirical researches are trying to find the benefit of accounting information value in order to improve financial report analysis. Many accounting empirical studies have attempted to find the relevance of accounting information value in order to enhance the financial report analysis. The relevance of accounting information value is a concept that discuss various meanings and sizes, related to accounting. Accounting information is predicted to have relevant value because it is related to stock market value (Barth et al., 2001).

Accounting info reflects company's performance quality that is translated into company's stock price. Accounting information analysis is useful for investors to predict share investments risk as presented by Koonce, et al. (2005). If the financial report gives significant benefits, the evidence will show that the market reacts to accounting information in the stages of company's appraisal. The process of stock speeds in responding information can be explained in Efficient Market Hypothesis (EMH).

\section{The Efficient Market Hypothesis}

The efficient market hypothesis studies are developed in accounting, in which every individual acts rationally to decision making. All service accounting users have a great desire in company value acquisition. Stock value movements is affected by financial statements that reflect prosperity level and its share holders through company's market value performance and sistematic pattern of information flow between companies in a particular industry.

About unefficiency market, it invites various criticism of a results study that is unable to give a good solution to the unsolved issues. Some studies gives unefficiencies evidence through abnormal return and in fundamental analysis it becomes studies' trigger market efficiency. The motivation to conduct earning management has broaden the concept toward agency contract agreement and political process has been a thinking point in market efficiency, including earning management objectives to affect stock price, since the investors and the market often have misperception about financial report in a position of over or under estimation. Lee (2001) not only supports the study of market efficiency, but also gives recommendation on behavioral finance of investor behavior analisys. The analogy of efficient market is a process and not a goal, Lee also suggested the future study on how, when or why the price adjustment process happened, including the process of arbitrage or trade off.

\section{The Signal Theory or "The Signaling"}

The signal theory explains how investors have the same information about company's prospects as its manager. It is called asymmetric information. But in reality, managers have better information than the investors. It is called informative asymmetri, and it has significant impact on optimal capital structure. In general, market believed that a high result dividend gives signal that the company has a good financial performance. This situation is supported by effective communication between company's management and investors. It also assisted by the good reputation to avoid other problems.

\section{The Measurement Concept of Corporate Market Value Performance}

Tucker and Zarowin (2006) used the earnings per share approach to measure the earning quality. The correlation is estimated between current and future earnings by using interaction between earnings per share and income smoothing. If the income smoothing improved the earning information, the correlation between current and future earnings will be improved too (the earning quality will increase). The test's results showed that interaction between earnings per share and income smoothing has a statistically significant positive relation. It confirms that income smoothing encouraged earning quality. The interaction between earnings per share and income smoothing is proven to 
have positive impact on stock return. The research above is called earning response coefficient (ERC) research, it measures the abnormal return level of securities market as a response on unexpected component of corporate earning report.

Dechow et al. (1994) developed a model with "Performance Based Discretionary Accruals" by adding ROA variable. Total accruals are used as a foundation to determine performance capabilities; earnings consist of total accruals and cash flows. The analysis results showed a negative correlation between significant accruals and cash flows, because the accruals additive factors positively related to earnings performance.

Francis et al. (2004) measure the earning quality (earnings persistence) from the regression slope coefficient of current earning on logged earning; he also showed that accruals quality has significantly positive effects on cost of equity. The earning quality can effect the dividend growth significantly and positively. Hanlon (2005) showed that the company give persistency of current earnings and has an ability to predict future earnings. It also gives additional information for investors. But this research is not related to dividend yield or dividend growth.

\section{Research methodology}

The research developed a framework of thinking through the image below:

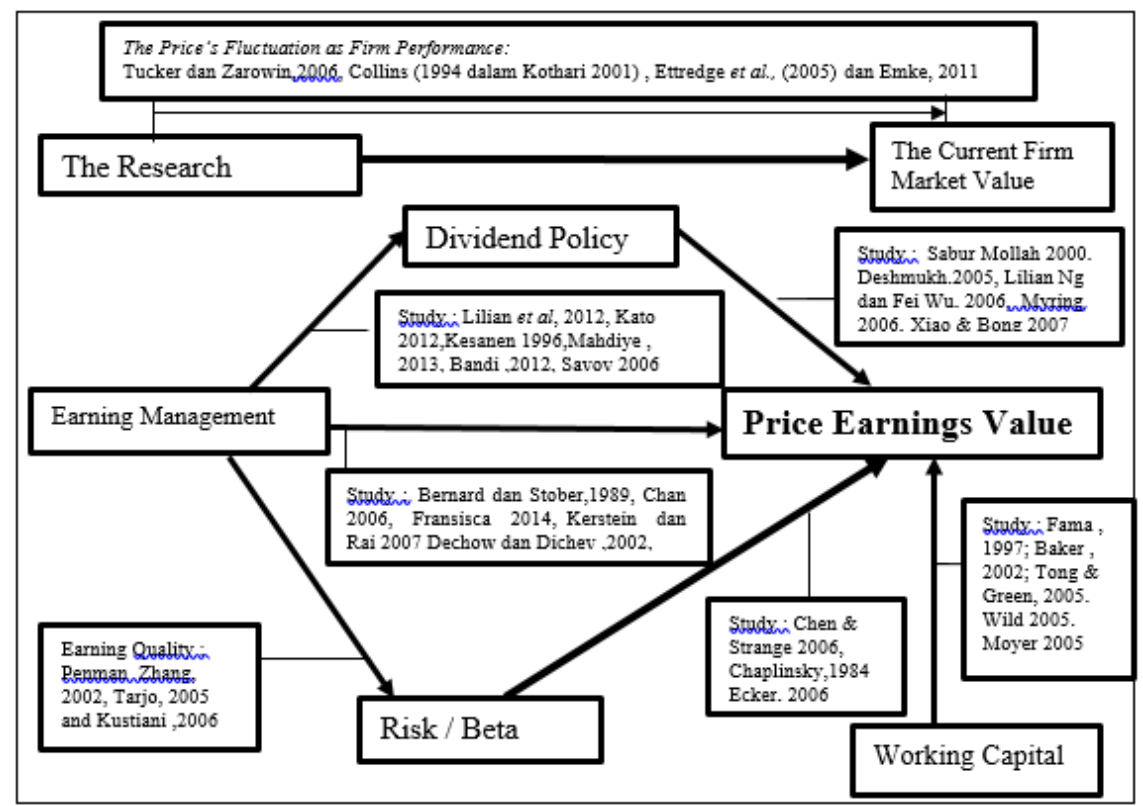

Source: Authors' own research

Figure.

Reasearch Framework

Based on the research framework above, the research hypothesis can be stated as follows:

H1: Dividend Pay Out has positive influence on Price Earnings Value.

$\mathrm{H} 2$ : Earning Management has positive influence on Price Earnings Value,

$\mathrm{H} 2 \mathrm{a}$ : Accrual's impact on the dividend policy

$\mathrm{H} 2 \mathrm{~b}$ : Accrual's impact on the working capital management.

H3 : Risk has positive influence on Price Earnings $k$ Value.

H4 : Working Capital has positive influence on Price Earnings Value.

The unit of analysis in this research are companies listed in Jakarta Stock Exchange during 14 years (2001-2014). This testing has gathered 2530 obsservation but

Muljanto Siladjaja and Yuli Anwar. The Impact of Earning Management on Market Earnings Value: The Causal Study on The Level of Accruals 
1350 observation are confirmed as valid. This research employed secondary data to run the path analysis in interaction modelling between variables.

The empirical test has distinguished management's behavior in publishing financial report with positive dan negative accruals. The level of accruals is related to the conservative level in conducting accounting treatment. When the accruals are low, it indicates that company is using a high conservative level, but when the accruals are positive, it indicates that the company is using a low conservative level, and indicates that there is a company management's opportunistic on company's prospect.

\section{Research Variables}

Based on explanation above, the variables' formulation is structured as follows:

Table.

The Eplanation of Indicator Variables

\begin{tabular}{|c|c|c|}
\hline Variabel & Dimension Indicator & Reference \\
\hline $\begin{array}{l}\text { Earning } \\
\text { Management }\end{array}$ & Discretionary Accruals ( $t$ and $t+1$ ) & Kothari (2005), Ohlson (2006) \\
\hline Cost Of Debt & $\begin{array}{l}\text { Ratio Cost Of Debt }=\text { (Cost Of } \\
\text { Debt)/ Net Revenue }\end{array}$ & Chen et al (2006), Binsbergen (2010), \\
\hline Dividend & $\begin{array}{l}\text { Dividend Pay Out = Dividen / } \\
\text { Earning } \\
\text { Dividend Pay Out } d(t \text { and } t+1)\end{array}$ & $\begin{array}{l}\text { Tong (2005), Deshmukh (2005), Xiao \& } \\
\text { Bong (2007) }\end{array}$ \\
\hline Working Capital & $\begin{array}{l}\text { Net WC=Current Asset-Current } \\
\text { Liabilitiesr } \\
\text { Ratio WC= WC/Current Asset }\end{array}$ & $\begin{array}{l}\text { Barth, (2001), Chan, (2006) } \\
\text { Dechow\&Dichev (2002),Sloan (1996). }\end{array}$ \\
\hline $\begin{array}{l}\text { Performance } \\
\text { Market Value }\end{array}$ & Ratio PER=Price/Earnings & $\begin{array}{l}\text { Tucker et al (2006), Emke, (2011), Dechow } \\
\text { et al (2002), Eldomiaty (2005), }\end{array}$ \\
\hline Resiko & $\begin{array}{l}\text { Beta (Varians ROA) } \\
\text { Standard Deviation Return On } \\
\text { Asset (period } 5 \text { tahun) }\end{array}$ & $\begin{array}{l}\text { Chen et al (2006), Chaplinsky,(1984), } \\
\text { Ecker,(2006) Penman et al (2002), Dechow } \\
\text { et al (2002), }\end{array}$ \\
\hline Cost Of Equity & $\begin{array}{l}\text { Model Ohlson } 1995 \\
r=(B t+X t+1-P t) / P t \text { dimana } \\
E_{(t+1)=} X_{t+1}+\delta\end{array}$ & $\begin{array}{l}\text { Ohlson (1995), Botosan (2007) Francis, } \\
\text { (2004). Supanvanij. (2006), Myring(2006), }\end{array}$ \\
\hline
\end{tabular}

\section{Measurement Indicators of Earning Management: Discretionary Accruals}

In this research, the earning management measurement model through Discretionary Accruals (DAC) indicator is the total result difference between Total Accruals (TAC) and Non Discretionary Accruals (NDAC). For obtaining the Discretionary Accruals, the calculation is conducted through Non Discretionary Accruals (NDAC) as a prediction value or fitted value. The Kothari Model is assumed as the best model, Cespa (2007) and Ohlson (2006) stated that the model increases the explanatory item, until 50\% from the average $39 \%$, reducing the earning management error measurement. The company's performance is measured with ROA to control the non-discretionary accruals. $\mathrm{ROA}$ is considered to have systematic relationship that is unexpected non zero towards accruals.

\section{Modelling of Path Analysis : Earnings Management and PER}

This study uses discretionary accruals that is directly tested with stock exchange value with modelling PER pattern. P/E ratios showed a higher level of strong growth prospect when all ratios are in the lowest level from a high risk company. When the company has a below average $\mathrm{P} / \mathrm{E}$ ratio, it recommends that the company has a high risk and low growth expectation. By using the same modeling with the previous analysis path 
model (with PBV indicator), the charts below are made to see the interactive relationship with PER.

\section{Accruals Positive}

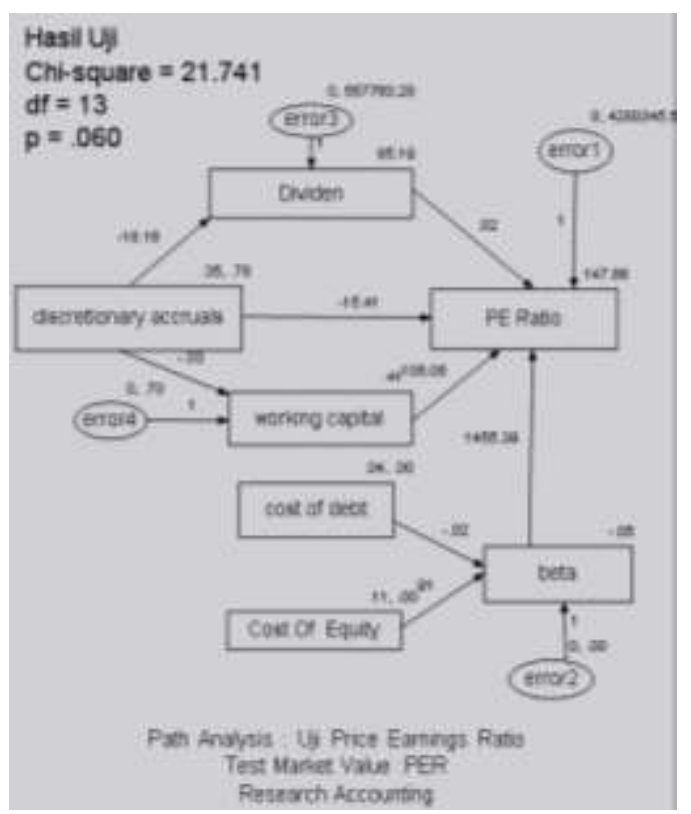

\section{Accruals Negative}

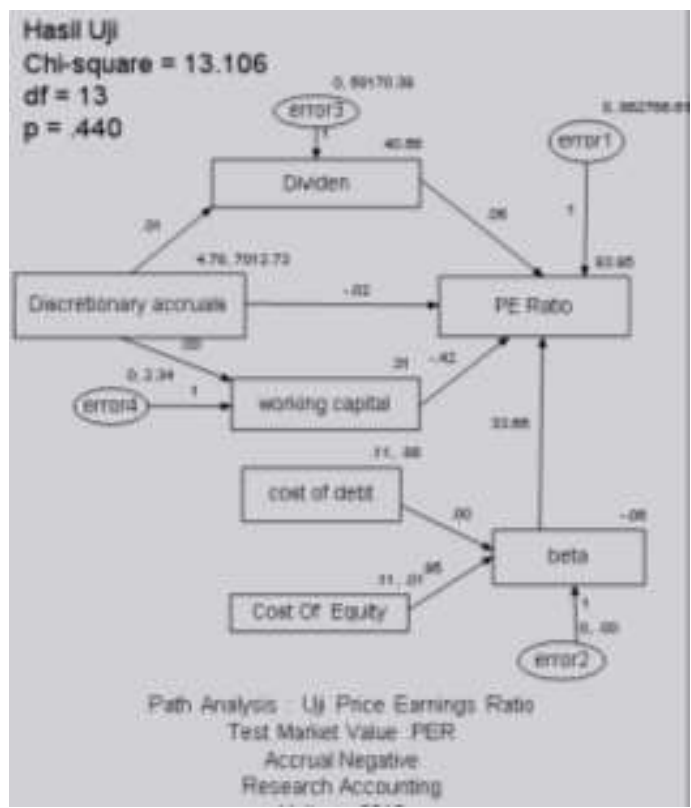

Source: Authors' own research

Figure.

Relationship Model Market Value Performance by PER

The model is written as the following equation:

$$
\begin{gathered}
\text { PER = } \beta 1 \text { Dividen }+\beta 2 \text { Working Capital }+\beta 3 \text { Resiko }+\beta 4 \text { Discretionary Accruals }+ \text { Z1 } \\
\text { (Error) } \\
\text { Beta }=\beta 5 \text { Cost Of Debt }+\beta 6 \text { Cost Of Equity }+ \text { Z2 (Error) } \\
\text { Working Capital }=\beta 7 \text { Cost Of Debt }+\beta 8 \text { Discretionary Accruals }+Z 4 \text { (Error) } \\
\text { Dividen }=\beta 9 \text { Discretionary Accruals }+Z 3 \text { (Error) }
\end{gathered}
$$

The multiple regression has been formulated, as below:

By using the measurement of the positive accruals

PER $=0.02$ Dividen +105.05 Working Capital -15.41 Discretionary Accruals +1455.3

Risk +0.42

Beta $=0.91$ Cost Of Equity -0.02 Cost of Debt +0.00

Working Capital $=-0.03$ Discretionary Accruals +0.70

Dividen $=-19.16$ Discretionary Accruals +0.55

By using the measurement of the negative accruals

PER $=0.05$ Dividen - 0.42 Working Capital - 0.02 Discretionary Accruals +33.66 Resiko+ 0.90

Beta $=0.95$ Cost Of Equity +0.00 Cost Of Debt +0.00

Working Capital $=0.00$ Discretionary Accruals +0.23

Dividen $=0.01$ Discretionary Accruals +0.58

Based on the this test, it can be seen that: 
1. Company that use positive and negative accruals has a same pattern in some variables, like dividend pay out, and beta (risk).

2. Company that use positive and negative accruals has a different pattern in some variables, like working capital, dicretionary accruals, and cost of debt.

By doing the empirical testing, the hypotheses are concluded as below:

Table.

The Difference Between Accruals Positive and Negative

\begin{tabular}{|l|l|l|l|}
\hline The Description & Accruals Positive & Accruals Negatif & Remarks \\
\hline The First Hypothesis & Positive & Positive & Similar \\
\hline The Second Hypothesis & Negative & Negative & Similar \\
\hline H2a (Impact on Dividend) & Positive & Negative & Different \\
\hline H2b (Impact on Warking Capital) & Negative & Zero & Different \\
\hline The Third Hypothesis & Positive & Positive & Similar \\
\hline The Fourth Hypothesis & Positive & Negative & Different \\
\hline
\end{tabular}

By doing the Discretionary Accruals against PER, the testing used PER to support previous research, the results are shown as below:

1. Dividend policy is not directly able to increase PER value, or dividend policy does not improve company's performance. It happened when accruals are positive or negative.

2. When accruals are positive, there is a relationship between working capital with PER or with company's performance. In other words, when the accruals are negative, the relationship becomes negative. It indicates that there is conservative pattern in company's management.

3. When using PER, the usage of earning management happens when dividend policy is applied with negative accruals, it reinforces the conservative pattern and cashflow effect.

4. There is relationship between PER and negative and positive rest level on negative and positive accruals usage, it indicates that a company use negative accruals gives rewards based on rise improvement, while with negative accruals, the company tried the things reversely.

Earnings management affect capital cost positively. The higher the accruals level, the higher the capital cost. Earning management affects capital cost significantly. The objective of earning management is to repair measurement of both risk. These risks are divided into two components, they are:

- Risks related to yield that is counted by price per share (price per earning).

- Risks related to finance structure that is counted with debt equity ratio.

By conducting the study using PER, The path analysis result of the above picture can be seen as below.

Tabel.

Criteria Path Analysis for (PER)

\begin{tabular}{|c|c|c|c|c|}
\hline Criteria & $\begin{array}{c}\text { The Critical } \\
\text { Value }\end{array}$ & $\begin{array}{c}\text { Accruals } \\
\text { positif }\end{array}$ & $\begin{array}{c}\text { Accruals } \\
\text { negatif }\end{array}$ & Interpreting \\
\hline Chi-Square & More Less & 21.741 & 13.069 & Fit \\
\hline Probability & $\geq 0,05$ & 0.06 & 0.440 & Fit \\
\hline RMSEA & $\leq 0,08$ & 0.045 & 0.04 & Fit \\
\hline CMIN/DF & $\leq 2,00$ & 1.672 & 1.008 & Fit \\
\hline TLI & $\geq 0,95$ & 0.975 & 1 & Fit \\
\hline CFI & $\geq 0,95$ & 0.989 & 1 & Fit \\
\hline
\end{tabular}

Muljanto Siladjaja and Yuli Anwar. The Impact of Earning Management on Market Earnings Value: The Causal Study on The Level of Accruals 
The Accounting Journal of BINANIAGA Vol. 04, No. 02, December 2019

p-ISSN: $2527-4309$, e-ISSN: $2580-1481$

$5^{\text {th }}$ Accreditation Rating: January 14, 2019 - January 13, 2024

\begin{tabular}{|c|c|c|c|c|}
\hline Criteria & $\begin{array}{c}\text { The Critical } \\
\text { Value }\end{array}$ & $\begin{array}{c}\text { Accruals } \\
\text { positif }\end{array}$ & $\begin{array}{c}\text { Accruals } \\
\text { negatif }\end{array}$ & Interpreting \\
\hline $\begin{array}{c}\text { Degree of Fredom } \\
\text { (DF) }\end{array}$ & Positive $(+)$ & 13 & 13 & Fit \\
\hline
\end{tabular}

The result showed that there is a compliance of determined criteria, this research testing has significant contribution among variables relationship. This testing supports previous test, including the fulfilment of minimum critical value. Based on the research above, it can be concluded that earning management positively influences company's performance through PER ratio. The higher the earning management performed by the company in manipulating its earning, the higher the capital cost because the level of information risk will be higher as well. The consequences is that the investors will raise the capital cost rate. The company maximize its earning in order to increase its stock price. It makes the dividend returned to investor will be higher too. The management has incentive or even disincentive to disclose information extensively.

Francis, et al (2004) assumed, if the company minimize its earning, such as to decrease the earning, it will get higher risk, then the capital cost will be higher too. With earning management investors will react by raising the dividend level that eventually increase the capital cost. The research of Jeong and Kim (2013) related to earnings management has an effect on cost of equity raising. For long-term investment, the decision making based on comparison of return's rate is expected higher than company's capital cost. For the most shareholders, the measurement of capital cost becomes an indicator to see the profit of investment directly and it may minimize the bias when predicting the next profit. The point is that there is a correlation between capital cost with earning management (Philippe et al, 2005).

In general, the research results indicate that a company that use negative accruals gives some different indicator with a company that use positive accruals. The usage of positive accruals demonstrates the application of conservative level to reduce the risk level, related with earning quality concepts. In this test, by using the level of variable control measurement and market value, it can be proved obviously that there is a difference on dividend policy and working capital on market value. Earning management's application affects financial report. The results of path analysis proved that working capital is a sensitive indicator in company's earning report and dividend policy. By doing this, we can see the company's capability in sending signals.

The mapping of decision tree model between management behavior and investor reaction can be seen in the following figure.

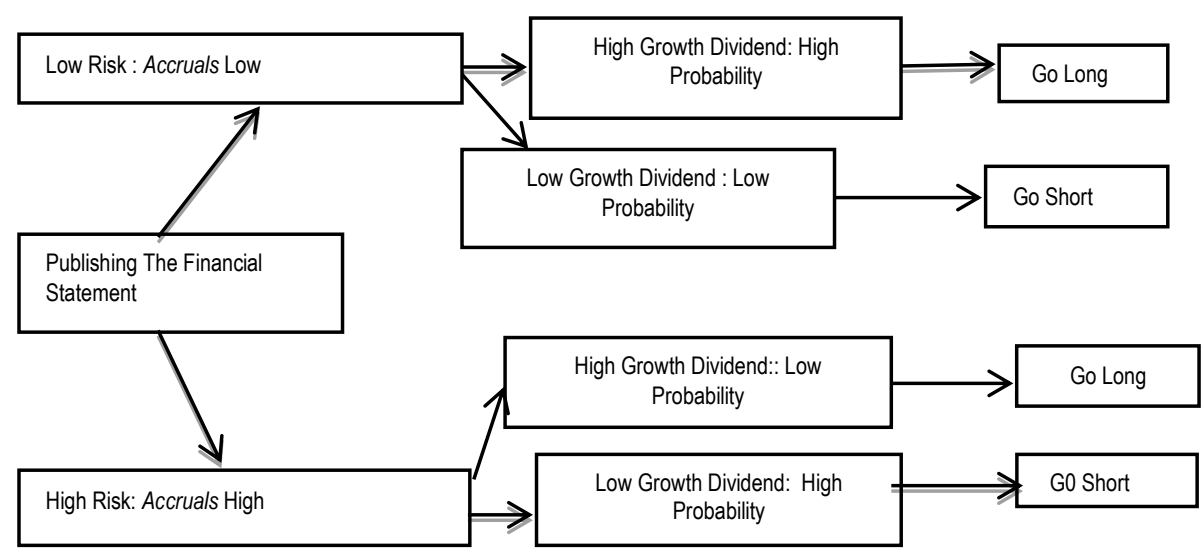

Note : The empirical result Go Short $=$ to sell $\quad$ Go Long $=$ To purchase

Source: Authors' own research

Figure.

The Mapping of Investor Reaction

Muljanto Siladjaja and Yuli Anwar. The Impact of Earning Management on Market Earnings Value: The Causal Study on The Level of Accruals 


\section{Conclusion}

Firms running positive and negative have the same pattern in implementing dividend pay out policy, because this variable gives positive contribution to market earning value. Dividend plays a critical role to level up price earning ratio, on the side the financial reporting have a misleading information, it means the opportunistic behaviour could be always existed.

Because of misleading information on market earning book performance, it has made bias information for investor to estimate firm performance in the future. The higher earning management the firm has, the lower the market earning ratio. By implementing high accruals, management sends out the message that the firm has been on the right track.

1. By looking over relation between dividen and earning management, it is proven that a firm in positive accruals has negative contribution on this relationship. It means that management uses high accruals in implementing dividend pay out, including negative working capital.

2. By looking over between the relationship between dividen and working capital, it is proven that a firm in negative accruals has positive contribution on this relationship. It means that management uses low accruals in implementing dividend pay out, including positif working capital.

The firm running the positive and negative have similar pattern in looking over the firm's risk. Based on the measurement on market earning value, there is positive contribution to this firm prospect. A firm which have positive accruals has higher risk level than the one which have negative accruals. It means the implementing accruals have been capable of boosting up the risk, but the less riskier is the firm which have negative accruals.

Based on the measurement of price earning value, the firm running the positive and negative has different pattern in looking over the firm's working capital. It means that the management using earning management to level up working capital is supported by this empirical finding, because the higher the accruals, the higher the working capital. When a firm has negative accruaks, this testing shows a negative relationship between earning management and working capital.

\section{Research's Limitation}

This research has limitation problem in illustrating management's behaviour in publishing financial reporting, including background and subjective judgement as one intergrated model. The research objectives are also limited to the investor's anticipation toward the benefit of financial report through investment decision. Other limitation is of financial report in estimating the probabability of investor's choice after publication period. The next researchers can develop better model that use primary and secondary data in one model related to the motive of earning management .

\section{References}

Barth, M.E., Cram, D.P. and Nelson, K.K.(2001), "Accruals And The Prediction Of Future Cash Flows", The Accounting Review, Vol. 76, No. 1, pp. 27-58.

Bollen, K. A.(1989), "Structural Equation Models with Latent Variables”. New York: John Wiley and Sons, Ltd.

Cespa, G. dan G. Cestone. (2007). "Corporate Social Responsibility and Managerial Entrenchment". Journal of Economics and Management Strategy. Vol.16, No. 3, pp.741-771. 
The Accounting Journal of BINANIAGA Vol. 04, No. 02, December 2019

p-ISSN: 2527 - 4309, e-ISSN: $2580-1481$

$5^{\text {th }}$ Accreditation Rating: January 14, 2019 - January 13, 2024

Chan, K; L.K.C. Chan; N. Jekadeesh; and J. Lakonishok. (2006). "Earnings Quality and Stock Returns" Working Paper Series, , University of Illinois at Urbana-Champaign.

Cohen, Daniel A. dan Paul Zarowin. (2010). "Accruals-Based and Real Earnings Management Activities Around Seasoned Equity Offerings". Journal of Accounting \& Economics. Vol. 50 No. 1, pp. 2-19.

Dechow, P.M and I.D. Dichev. (2002). "The Quality of Accruals and Earnings: The Role of Accruals Estimation Errors", The Accounting Review, Vol. 77.

Dechow, P.M, (1994). "Accounting Earnings and Cash Flows as Measures of Firm Performance: The Role of Accounting Accruals", Journal of Accounting and Economics, Vol. 18, pp. 3-42.

Deloof, D. 2003. "Does Working Capital Management Affect Profitability Of Belgian Firms?" Journal of Business Finance and Accounting, Vol 30, No 3 \& 4, pp. $573-$ 587.

Francis, J.; R. La Fond; P.M. Olsson; and K. Schipper. (2004). "Costs of Equity and Earnings Attributes", The Accounting Review, Vol. 79, No. 4, pp. 967 - 1010.

Fransisca Fortunata Gunawan, Felizia Arni Rudiawarni, Aurelia, CC Sutanto, (2014), "Hubungan Antara Financial Distress Dengan Earnings Management Pada Badan usaha Sektor Manufaktur Yang Terdaftar Pada BEl Periode 2010-2012", Jurnal IImiah Mahasiswa Universitas Surabaya, Vol 3, No. 1.

Hanlon, M. (2005). "The Persistence and Pricing of Earnings, Accruals, and Cash Flows When firms Have Large Book-Tax Differences", The Accounting Review, Vol. 80, No. 1, pp. 137 - 166.

Jeong-Bon Kim, Byungcherl Charlie Sohn, (2013) "Real Earnings Management And Cost Of Capital”, Journal. Account. Public Policy, Vol. 32, pp. 518-543.

Koonce, Lisa Mary Lea Mc Anally, and Molly Mercer, (2004), "How Do Investor Judge the Risk of Financial Item", Working Paper Od University Of Texas.

Lazaridis I, Tryfonidis D, (2006). "Relationship Between Working Capital Management and Profitability of Listed Companies in the Athens Stock Exchange". Journal of Financial Management and Analysis, Vol.19, pp. 16-25.

Lee, Charles M.C., (2001), "Market Efficiency And Accounting Research: A Discussion Of 'Capital Market Research In Accounting' By S.P. Kothari“ Journal of Accounting and Economic, Vol. 31, pp. 233-253

Leuz, C., Nanda, D., \& Wysocki, P. (March 2003). "Earnings Management And Investor Protect-Tion: An International Comparison”. Journal of Financial Economics. 69.

Myring, Mark (2006), "The Relationship Between Returns And Unexpected Earnings: A Global Analysis By Accounting Regimes“, Journal of International Accounting, Auditing and Taxation, Vol. 15, pp. 92-108.

Ohlson, J.A. (2006). "A Practical Model of Earnings Measurement.", The Accounting Review, Vol. 81, No. 1, pp. 271 - 279.

Philippe Gaud, Elion Jani, Martin Hoesli, dan Andre Bender. 2005," The Capital Structure of Swiss Companies: an Empirical Analysis Using Dynamic Panel Data" Available from: URL: http:/www.Proquest.com

Muljanto Siladjaja and Yuli Anwar. The Impact of Earning Management on Market Earnings Value: The Causal Study on The Level of Accruals 
Prima Santy, Tawakkal, Grace T. Pontoh, 2012,"Pengaruh Adopsi IFRS Terhadap Manajemen Laba Pada Perusahaan Perbankan Di Bursa Efek Indonesia", Penelitian Unhas, Makasar 2012.

Penman, S.H and X.J. Zhang. 2002. "Accounting Conservatism, the Quality of Earnings, and Stock Return", The Accounting Review, Vol. 77, No. 2.

Sylvia Veronica N.P. Siregar, dan Siddharta Utama, CFA, 2005, "Pengaruh Struktur Kepemilikan, Ukuran Perusahaan, Dan Praktek Corporate Governance Terhadap Pengelolaan Laba (Earnings Management)", Simposiun Nasional Akuntansi VIII . Solo, 15 - 1. Pp. 475.

Teoh, S., Welch, I., and Wong, T., 1998a, "Earnings Management And The Long Run Market Performance of Initial Public Offerings", The Journal of Financial, Vol. 6, pp.53-74.

Tucker, J.W. and P.A. Zarowin. (2006). "Does Income Smoothing Improve Earnings Informativeness?", The Accounting Review, Vol. 81, No. 1, pp. 251 - 270. 
The Accounting Journal of BINANIAGA Vol. 04, No. 02, December 2019 p-ISSN: $2527-4309$, e-ISSN: $2580-1481$

$5^{\text {th }}$ Accreditation Rating: January 14, 2019 - January 13, 2024

This page intentionally be emptied.

Muljanto Siladjaja and Yuli Anwar. The Impact of Earning Management on Market Earnings Value: The Causal Study on The Level of Accruals 